Daimon. Revista Internacional de Filosofía, $n^{\circ} 76,2019$, pp. 35-49

ISSN: 1130-0507 (papel) y 1989-4651 (electrónico)

http://dx.doi.org/10.6018/daimon/267521

\title{
The Idea of the Politics of Realisation in José Ortega y Gasset
}

\section{La idea de política de realización en José Ortega y Gasset}

DOROTA LESZCZYNA*

\begin{abstract}
The goal of my article is to present the idea of the politics of realisation as defined by Ortega. This philosopher made his mission the fight for "new vital Spain" that could be made real through its Europeanisation. The vision of political activities proposed by Ortega was different from the traditional one. It was not focused on soliciting for votes and keeping the power but its goal was to exploit the potential of the nation and to grow the vitality of Spain. Such perspective of 'Politics' became for Ortega the politics of realisation. It was the result of overcoming political idealism and naïve realism. Ortega abolished the aforementioned standpoints and specified his own project of critical realism in the form of the politics of realisation. For him, the realisation means the "higher imperative in the area of politics". It draws the attention to the fact that the purpose already includes the realised activity. It does not act against the ideal but draws it from the real structure of things and not from our subjective desires and ideas.

Keywords: Ortega, politics, realisation, idealism, realism, overcoming
\end{abstract}

\begin{abstract}
Resumen: El objetivo de mi artículo es presentar la idea de política de realización en Ortega. La actividad intelectual orteguiana toma como misión construir una España nueva y vital a través de su europeización. La visión orteguiana de la política es bien diferente a la tradicional. En tanto la política electoral, parlamentaria y gubernativa consiste en conquistar votos y, en consecuencia, el poder de legisladores y de gobernantes; Ortega tiene un concepto más amplio de "política", que abarca toda la serie de acciones encaminadas a socializar la vida nacional. La política, así, sería un motor que activa a los individuos para que realicen cada día su propia vida y, a la vez, la idea y las posibilidades de su nación. Esta política se llama en Ortega "política de realización". Es resultado de superar el idealismo y realismo ingenuo en el área política. Ortega superando las limitaciones en ambas doctrinas crea su propio proyecto del realismo crítico cuya manifestación es su idea de la política de realización. La realización significa para él "el mandamiento supremo que define el área política”. Así política de realización no rechaza el ideal, sino que lo busca en la estructura real de las cosas y no en nuestros deseos e ideas que son siempre subjetivos.

Palabras clave: Ortega, política, realización, idealismo, realismo, superación
\end{abstract}

Recibido: 12/09/2016. Aceptado: 15/06/2018.

* Dorota Leszczyna is a Ph.D. with habilitation (post-doctoral degree) in Philosophy at the University of Wroclaw (Poland) and a PhD in Political Science at the University of Alicante. She is an assistant professor at the Department of Modern Philosophy of the University of Wrocław. Her research interest lies primarily in Spanish philosophy of the nineteenth and twentieth centuries and the German philosophy (Kant, German idealism, neo-Kantianism). She is the author of three monographs devoted to Ortega y Gasset published in Poland. She published also in Revista de Estudios Orteguianos (2015); Contrastes. Revista Internacional de Filosofía (2015) and in Análisis. Revista de Invesigación Filosófica (2017). Her recent publications include: La presencia de Paul Natorp en la filosofía social de Ortega, en: Ortega y los tiempos de las masas, ed. H. Aznar, E. Alonso Robero, M. Menéndez Alzamora, Madrid: Plaza y Valdéz, 2018, p. 25-40 and Interpretación de Ortega y Gasset de la filosofía de Kant: del idealismo marburgués a la ontología crítica, "Análisis. Revista de investigación filosófica”, vol. 4, n. . 1 (2017), pp. 25-48 


\section{Introduction ${ }^{1}$}

José Ortega y Gasset (1883-1955) is undoubtedly the best-known and the most regarded modern Spanish philosopher. He became famous for his standpoint of 'raciovitalismo', as an excellent journalist, essayist and sharp-witted observer of transformations in cultural, social and political reality. He always viewed his intellectual activity in terms of mission that was to serve the prosperity of Spain. For him, it was the all-important circumstance that he - according to his philosophical message - wanted to save to save himself. This circumstantial character of Ortega's philosophy demanded that "his Spanish fate is accepted completely and without reservations" ${ }^{\prime 2}$ by him and its essential part became the fight for new vital Spain that he wanted to create based on its Europeanisation. For him, Europe meant the philosophical and scientific tradition based on reason with the German culture as its greatest manifestation ${ }^{3}$. Pursuant to Ortega, the Germans created the culture which was not affected by individualism and was based on pure methodology whose reception did not threatened with the loss of identity and national uniqueness.

Therefore, Spain did not have to be afraid of being 'conquered' by Germany or the invasion of 'foreign influences' to its territory ${ }^{4}$. Thus, it could transform the German culture into its own pedagogical idea and draw the rules of reliable and systematic scientific and philosophical research from it.

Ortega viewed Spain as a problem, while Europe - especially Germany - were the solution. This relation, however, should not be associated with any form of mimetism as Spain was to provide a new interpretation for the ideas drawn from the European culture in accordance with its own temperament. Thus, it was to fulfil its mission through getting involved into the process of implementing the great idea of Europe. This perspective of the problem of Spain was the grounds for Ortega's involvement in the social and political life of his nation which changed him into an activist promoting the Second Spanish Republic and the creation of strong and self-conscious civic society therein ${ }^{5}$. Ortega was a co-founder of

1 This article is part of the research project: Idea polityki realizacji w ujęciu José Ortegi y Gasseta; Narodowe Centrum Nauki, "Opus 10", nr 2015/19/B/HS1/01010. This project has been developed and presented in my doctoral dissertation entitled: Del idealismo al realismo crítico. La política como realización de José Ortega y Gasset, defended on 29.09.2017 at the Faculty of Law at University of Alicante. The dissertation was written under the direction of Manuel Menéndez Alzamora, titular professor at University of Alicante.

2 José Ortega y Gasset, «Prólogo para alemanes», in Obras completas, Fundación José Ortega y Gasset-Taurus, vols. 10, Madrid 2004-2010, t. IX, p. 162.

3 On the German sources of Ortega's philosophy wrote the following thinkers: Nelson. R. Orringer, Ortega $y$ sus fuentes germánicas, Gredos, Madrid 1979; Pedro Cerezo Galán, La voluntad de aventura. Aproximamiento critico al pensamiento de Ortega y Gasset, Ariel, Barcelona 1984; Ciriaco Morón Arroyo, El sistema de Ortega y Gasset, Alcalá, Madrid 1968; J. Zamora Bonilla, Ortega y Gasset, Plaza y Janés, Barcelona 2002; K. Cramer, «Ortega y Gasset y la filosofia alemana», in Historia, lenguaje, sociedad, (eds.) M. Cruz, Crítica, Barcelona 1989, pp. 186-204; E. Garrigues, «Ortega en su circunstancia alemana», Humboldt 79 (1983), pp. 53-63; E. Garrigues, «Ortega y Alemania», Revista de Occidente 132 (1992), pp. 128-138 or J. San Martín, «Ortega en Alemania», in El Madrid de José Ortega y Gasset, (eds.) J. Lasaga Medina, Publicaciones de la Residencia de Estudiantes / Sociedad Estatal de Conmemoraciones Culturales, Madrid 2005, pp. 331-348.

4 José Ortega y Gasset, «Una respuesta a una pregunta», ibid., t. I, p. 462

5 Public activity of Spanish thinker analized Vincente Cacho Viu, Los intelectuales y la política. Perfil público de Ortega y Gasset, Biblioteca Nueva, Madrid 2000; G. Queipo de Llano y de J. Tusell, Los intelectuales y la 
such political groups as the Spanish League of Political Education established in $1913^{6}$ and the Group at the Service of the Republic founded in 19307. In the years 1931-1932, he was also the deputy to the Cortes in the province of León and participated in the works aimed at the enactment of the new Constitution (1931). Yet, Pedro José Chamizo Domínguez was right when he said: "the paradoxical situation of a philosopher 'entangled in politics' is repeated once again for he is listened to by the Cortes but is not followed"8. It resulted in Ortega's disappointment with parliamentary politics and consequently his withdrawal from active political life. There were several reasons for that. The most important of them being that Ortega's vision of political activities was yet different from the traditional one. For him, it was not focused on soliciting for votes and keeping the power but its goal was to achieve "the stimulation and growth of vitality of Spain"9, to restore the state to its citizens who would be committed to exploit the potential of their own nation ${ }^{10}$.

\section{The Concept Of 'Politics' In Ortega}

Ortega was convinced that - as the Spanish society was not equipped with all essential functions and the state authorities did not function properly - each Spanish citizen should become socially involved regardless of whether they wanted it or not. This necessity of intervention of citizens into the 'problem of Spain' required the establishment of appropriate basis for politics in a form of culture. Ortega interpreted culture as "the system of live ideas concerning the world and the humankind" 11 that should correspond to the spirit of the times, which means that it should be rooted in the life and respond to the problems arising from it. Therefore, he clearly distinguished 'politics' from his own concept of 'Politics'.

The first one has a narrow meaning and it operates mainly in deputies' offices and the Parliament. It consists in soliciting for votes and fighting for posts and its objective is the power. Pursuant to Ortega, the common politics is just an external function of living, a third- or fourth-rate civic activity. In such a way, the sensu stricte political problems constitute always just one sign of deeper and much more serious diseases being the disease of the entire nation - "its vital anaemia"12. The problem in traditional politics consists first of all in the fact that its representatives, that is politicians, do not comprehend the essence of

República, Narea, Madrid 1990, Paul Aubert, «Los intelectuales y la II República», Ayer 40 (2000), pp. 105-

135 or Manuel Menéndez Alzamora in his book, La generación del 14. Intelectuales y acción política, Catarata, Madrid 2015.

6 See reflection on this subject of Juan Bagur Taltavull, «José Ortega y Gasset en el movimiento reformista: la Liga de Educación Política Española como proyección del “patriotismo fenomenológico” (1913-1916)», Ab Initio 10 (2014), pp. 153-188.

7 See Alejandro Haro de Honrubia, «El advenimiento de la Segunda República española desde la óptica de José Ortega y Gasset: la importancia de la Agrupación al Servicio de la República (ASR)», La escarapela tricolor. El republicanismo en la España contemporánea, (eds.) Claudia Cabrero Blanco, KRK/Universidad de Oviedo, Oviedo 2008, pp. 409-423.

8 Pedro José Chamizo Domínguez, Ortega y la cultura española, Cincel, Madrid 1985, p. 37.

9 José Ortega y Gasset, «Vieja y nueva política», ibid., t. I, p. 718.

10 See about this subject article of Alejandro Haro de Honrubia, «El pensamiento político de José Ortega y Gasset», Annales de l Seminario de Historia de Filosofía 32 (2015), pp. 477-515.

11 José Ortega y Gasset, «Misión de la universidad», ibid., t. IV, p. 538.

12 José Ortega y Gasset, «Otra manera de pensar», ibid., t. III, p. 37. 
social life, do not have its clear and obvious definition and therefore they view it as an empty vessel that they fill in with the content selected at their discretion, depending on their needs, interests and whims. They think that politics is realised only "in their cabinets" and do not understand that social life relies on 'coexistence' and thus on cooperation ${ }^{13}$. Furthermore, they do not notice that the politician's mission comes down to being a 'citizen', an 'activist' who changes words into acts and fulfils the real potential inherent in the society and nation.

The second one is focused on working at the grass roots, that is education consisting in the activation of citizens and the creative potential in them and the activities aimed at the development of wide-ranging national culture and fulfilment of the goals and tasks set for it. The proper 'Politics' should be always aimed at future and should encompass readiness for searching new and increasingly better solutions. Therefore, the key role in Ortega's 'Politics' was occupied by the education interpreted as a root and branch reform of Spanish citizens' mentality aiming at their turn towards Europe and "stirring of cosmopolitan emotions in them"14. First of all, it is about arousing the enthusiasm for life in individuals, for its designing and accomplishing, and only after that - to get the individuals politically and socially involved. For Spain is not in crisis because of its politics but because the disease has reached the very substance of the nation and individuals living therein who are the catalyst for social and political transformations.

Such perspective of 'Politics' became for Ortega the politics of realisation (also called the 'realistic politics'). The studies and analyses of Ortega's philosophy carried out by me thus far, especially of its social and political aspects, are the grounds for stating that 'realisation' is a key notion therein. Ortega took it from Hegel and gave it his own interpretation. The notion of 'realisation' can be found in Hegel in the context of the problem of 'internal purpose'. Hegel thought that the purpose includes the "realised activity" whose definition is fulfilled by us in such a way that "whatever is created, it has to correspond to the purpose, $[\ldots]$ that the things cannot have anything more to them than just the purpose"15. It results in abolishing the subjectivity of the purpose and viewing it as an objective one, that is an idea constituting the unity of the notion and its reality Ortega, by contrast, started a creative dialogue with Hegel and pointed out that ideas and ideals cannot be abstract and empty but they should undergo their realisation ${ }^{16}$. The realisation assumes that the ideas and ideals should be objectively drawn from the structure of things and not subjectively from our notions of things or desires or demands towards things. It is also the basis of Ortega's criticism of the formula of "what it should be like" and the creation of ideal social bodies

13 José Ortega y Gasset, «Hacia una mejor política», ibid., t. III, p. 51.

14 José Ortega y Gasset, «La conservación de la cultura», ibid., t. I, p.153. See Pedro Cerezo Galán, «Experimentos de nueva España», in José ortega y Gasset y la razón práctica, Biblioteca Nueva, Madrid 2011, pp. 287-330.

15 Georg Wilhelm Friedrich Hegel, «Vorlesungen über die Geschichte der Philosophie I», in Werke in 20 Bänden, (hrsg.) E. Moldenhauer, K. M.Michel, Suhrkamp, Frankfurt/M 1971-1978, t. 18, p. 383. See Domingo Hernández Sánchez, Estética de la limitación. La recepción de Hegel por Ortega y Gasset, Ediciones Universidad de Salamanca, Salamanca 2000 and the work of Elena Acciaioli, «Ortega y Hegel: un diálogo fructífero», Revista de Estudios Orteguianos 27 (2013), pp. 247-249.

16 See about this philosophical relations in Clementina Cantillo, «La dinámica histórica entre energía mediterránea y pensamiento del norte: la confrontación de Ortega con Hegel», in La brújula hacia el sur, (eds.) P. Badillo O’Farrell y José M. Sevilla Fernández, Biblioteca Nueva, Madrid, pp. 87-100. 
according to the method of more geometrico ${ }^{17}$. Pursuant to Ortega, only those elements which are already present in the social reality should be realised, which means 'what is' and not 'what we subjectively wish to have'. Ortega viewed realisation as an imperative relevant to the area of politics which makes it fundamentally different from science. While the latter - given its theoretical objective - may or even has to have some pure, formal and even utopian elements, politics is the 'realisation' which means that there is no place for generalities, abstractions or formalities but only the place for precise and effective activities. Therefore, Ortega believed that in politics, there were no "general and fair principles" but only "specific and truthful acts" 18 .

In my opinion, the notion of 'realisation' also holds together all stages and transformations of Ortega's thought being the natural consequence of the internal development of Ortega himself, his philosophical, social and political maturation which encompassed his transition from idealistic standpoints to critical realism as he believed that this standpoint was "more demanding" both in metaphysics as well as in social and political philosophy ${ }^{19}$.

\section{The Critical Realism in the Area of Ortega's Political Philosophy}

Critical realism was a kind of an attempt to practice philosophy "outside idealism and naïve realism", to abolish the definite content of such standpoints and to develop higher synthesis corresponding to the spirit of the times. Such 'overcoming' of limitations inherent in those two extreme standpoints was for Ortega the task of his times which required "specific unification of Aristotle with Descartes", which unification would result in new, higher and more extensive standpoint ${ }^{20}$. The notion of 'overcoming' which - similarly to the notion of "realisation" - holds together Ortega's whole philosophy is a direct reference to Hegelian term of Aufhebung. For Hegel, it had double meaning: on the one hand, it meant "to put an end to something", and on the other hand - "to preserve something" 21 . 'To abolish' did not mean just 'to annihilate' but rather 'to free from directness'. In his Notas de trabajo devoted to Hegel, Ortega identified the German verb Aufheben with Spanish'absorber (take up, soak up, absorb) resumir (include, comprise, come down to), sumir en (plunge, sink) and resolverse en (dissolve, melt) ${ }^{22}$. He also referred to the Italian translation of this German verb used by Croce in his works and decided that it corresponded in terms of meaning to the Spanish word superar (overcome) ${ }^{23}$. This last notion was used by Ortega in his philosophy and was made by him its fundamental axis. Ortega's idea of the politics of realisation should be also considered in this context. It was the result of overcoming the political, ideal and naïve realism and thus constituted the negation of the definite content of those standpoints

17 José Ortega y Gasset, «España invertebrada», ibid., t. III, pp. 486-488.

18 José Ortega y Gasset, «Entreacto polémico», ibid., p. 801.

19 Ibid., p. 800

20 José Ortega y Gasset, «La filosofía de la historia de Hegel y la historiología», ibid., t. V, p. 245

21 Georg Wilhelm Friedrich Hegel, «Wissenschaft der Logik I», ibid., t. 5, p. 114

22 José Ortega y Gasset, Hegel. Notas de trabajo, (eds.) Domingo Hernández Sánchez, Fundación Ortega y Gasset / Abada editores, Madrid 2007, p. 31.

23 In the private library of Ortega are two works of Croce. The first one is Cio che è vivo e ciò che é morto della filosofia di Hegel, Bari 1907 and the second one is his translation of G. W. F. Hegel, Enciclopedia: Enciclopedia delle Scienze Filosofiche en compedio, Bari 1907. 
with simultaneous preservation of the elements existing there which were still important and which created a higher synthesis corresponding to the spirit of the times when enriched with new meaning.

For Ortega, idealism in political sphere was exemplified in abstract liberalism. Its mistake consisted in the affirmation of an empty idea of freedom as freedom is just a form, an empty vessel that should be filled with meaning and content. Therefore, Ortega criticised the central message of liberalism, that is "Freedom above all else" and replaced it with his own "Freedom and all" meaning all those elements which are necessary to realise the individual vocation of man ${ }^{24}$ and historical needs of a nation ${ }^{25}$. In his opinion, the adjective 'liberal' required a noun and politics - before becoming liberal - has to become the politics itself. This latter one means for him a historical standpoint, that is a conscious experience of the nation's life, its unceasing design, and the realisation of its potential and care for its future. The real 'Politics' is conscious of itself, passes into the soul of the nation and knows its substance. It knows that the history does not mean "the history of battles, fates of leaders, states or parliaments" but is "the expression of the nation's vitality, its bloodstream" 26 . Therefore, the idea of freedom promoted by the liberals was empty for Ortega, and thus worthless. For the idea to serve the nation has to be subject to its realisation, has to stem from life and create that life. Thus, the freedom proclaimed by the liberals requires the development and implementation of relevant measures to protect it and fulfil in social and political activities. "The Politics," wrote Ortega, "is equally the work of thought and willpower. It is not enough that some ideas come into somebody's head. It is necessary that they become realised in social terms" ${ }^{27}$.

For Ortega, politics cannot be founded on pure and abstract ideas which are always utopian but on the reality of concrete facts, in this case - the reality of the Spanish nation. The nation is thus above the abstractly viewed freedom and above "the mystical dilemma on which everything else should depend: the Monarchy or the Republic?"28. It is the fundamental reality and "the sole significance" 29 . Therefore, neither the Monarch, nor Republic, nor Freedom, nor Parliament may substitute the fundamental issue being the Nation ${ }^{30}$. In Ortega's case, the criticism of abstract liberalism is connected with his project of realistic philosophy in which he calls for faithfulness to things and avoids intellectual manipulations. It is based on phenomenology which is yet interpreted in anti-idealist spirit. The influence of Hegel's philosophy and his critical view of liberalism based on abstractly interpreted freedom is also present therein. Furthermore, Ortega applies Hegelian dialectics but deprives it of its strictly logical and rationalist level and replaces it with his own method of real dialec-

24 In this sense, Ortega does not equate liberalism with the political sphere, but rather funds it in the radical reality of the individual's life. As Haro de Honrubia rightly observes “(...) Ortega considera que el liberalismo ha de ser, en última instancia, más que un instrumento político, a saber: un sentimiento vital favorable a la vida individual o personal”. Alejandro Haro de Honrubia, «El pensamiento político de José Ortega y Gasset», Annales de l Seminario de Historia de Filosofía 32 (2015), p. 502.

25 José Ortega y Gasset, «Vaguedades», ibid., t. III, p. 791.

26 José Ortega y Gasset, «Vieja y nueva política», ibid., t. I, p. 717.

27 Ibid., p. 711.

28 José Ortega y Gasset, «Vaguedades», ibid., t. III, p. 791.

29 Ibid.

30 See about this subject Juan Bagur Taltavull, «La idea de nación en Ortega y Gasset: estado de la cuestión», $A b$ Initio 7 (2013), pp. 125-160. 
tics aimed at reversing the subject-object relation and abolishing idealism. For the necessity of dialectical thinking is inherent not in the very structure of a thinking subject but in the object of thought. The reality is of defined-undefined nature and therefore it is dialectical. When viewed this way, it is not the thinking that imposes its rights but vice versa - the reality imposes them on the thinking. Therefore, Ortega said that "reality is the master and teacher of human beings" and its structure does not come from the subject. It was Ortega's method of overcoming the empty and abstract character of liberalism and establishing a new relation between what is real and what is ideal, between what is (reality) and what it should be like (thinking of reality). He emphasised that the ideal was not something opposing to a thing but something that came into being along with it as a margin of its possible perfection. In such a sense, the realisation of the ideal means the perfection of the real structure of the surrounding world.

Abstract liberalism falls into idealist misconception where the things are reduced to intimate and internal conditions of the subject and are valued according to the formula of "what it should be like". It gives priority to general ideas, without their concretisation or filling them in with content. It causes that such ideas seem to "function alone" without any connection with the reality. It was the reason for the emergence of Ortega's project aimed at establishing the realistic politics based on liberalism, yet on such liberalism in which the things - and not our ideas about them - come to the forefront. That liberalism was to be "truthful, intriguing and concrete" 31 . As Ortega said, it had to be "a greater friend of life and the trigger of enthusiasms" 32 . Furthermore, its mission was the nationalisation of freedom which places the said freedom in specific Spanish circumstances, its definition from the perspective of historical needs and limitations of the nation.

While For Ortega, the naïve realism in politics was exemplified by pragmatism and materialism which neither respect the ideals nor create them. They present the politics that is 'idolatrous', egoistic, aimed at satisfaction of particularistic needs and interests, and their basis is the culture of measures and not of goals ${ }^{33}$. Furthermore, Ortega rejected all political standpoints which - through affirming the facts - do not notice the need for changing and reforming of the social reality based on the ideals drawn therefrom.

Realistic politics cannot be limited only to facts, to what is. It cannot fail to notice the need for development, reforms, perfection and transcending of reality. It cannot be the politics which does not look forward or that is missing imagination, daring, and ability to create and design life. In such a sense, the realistic politics does not reject ideals but - in opposition to idealism - does not extract them only subjectively from our notions and ideas about the reality but also objectively from the reality itself which - pursuant to Ortega - is "a wonderful mine of ideals" 34 . For the reality is not something given, static and permanent but something that is going on, creating, is a mutual and dynamic "happening" of a human being and their circumstances.

Ortega - through abolishing the content of the aforementioned standpoints, that is in liberalism - its formalism and abstractly interpreted freedom, in pragmatism, progressivism

31 José Ortega y Gasset, «Al entrar en liza», ibid., t. III, p. 246

32 Ibid.

33 José Ortega y Gasset, «Entreacto polémico», ibid., t. III, p. 800.

34 José Ortega y Gasset, «Estética en la tranvía», ibid., t. II, p. 181. 
and materialism - their egoism, lack of concentration on ideals - specified his own project of critical realism in the form of the politics of realisation in which the path to goal, the community effort in achieving it are more important than its ultimate achievement ${ }^{35}$. For him, the realisation means the "higher imperative in the area of politics" 36 . It does not act against the ideal but draws it from the real structure of things and not from our subjective desires and ideas. It is not about the creation of ideal social organism based on more geometrico, about the subordination of facts to our ideas (utopianism) but about the "observation of reality with humble attitude" in order to introduce the ideas on its basis and to fulfil the most urgent historical needs of the nation ${ }^{37}$. The politics of realisation is aimed at transforming of the reality in accordance with our ideas. Yet, it simultaneously shows that such ideas should be drawn from the real structure of things and not subjectively "from our heads". For in this latter case, we only express our wishful thinking, which does not enable us to shape the surrounding reality. Therefore, Ortega called for rejection of the so-called "logic of our desires" 38 . It shows the mentality of a child or an immature man who cannot distinguish between the reality and their own ideas of it. Such a man considers the reality as "soft and magic matter that submissively adapts to the patterns of their ambition" 39 .

Therefore, Ortega - following Kant - affirmed the exit of a man from the condition of immaturity that he interpreted in accordance with his concept of politics. It was based on the statement that the world of things is permanent and its matter resists our activities. At the same time, it leaves for us a narrow margin of possible transformations which consist in developing and improving whatever we find in that world. It is also the grounds for Ortega's definition of life as work and effort undertaken to save our circumstances. Thus - pursuant to Ortega - it is necessary to get rid of wishful thinking and demanding attitude, once and for all, towards the world manifested in false belief that the world should yield to our whims and wills. Therefore, the politics of realisation is such politics which draws conclusions from the observation of the nation's life and such conclusions concern its most urgent historical needs. It is the politics that strives for improving those elements which are already present in the nation. For Ortega, the nation was a task consisting in the exploitation of the potential inherent in it, which required the commitment of citizens, the development of citizenship in them as well as the responsibility for their own acts ${ }^{40}$.

\section{The Idea of Politics of Realisation and its Characterisctics in Ortega}

Ortega's idea of politics of realisation outlined hereinabove and my existing research into Spanish philosophy are the grounds for the formulation of several research theses.

35 See Alejandro Haro de Honrubia, «La idea de progreso en la era del nihilismo: Ortega y su crítica al progresismo», Revista de la Escuela Universitaria de Magisterio de Albacete 18 (2003), pp. 133-154.

36 José Ortega y Gasset, «Entreacto polémico», ibid., p. 800.

37 See José Ortega y Gasset, «España invertebrada», ibid., p. 486.

38 José Ortega y Gasset, «Mirabeau o el Político», ibid., t. IV, p. 195.

39 Ibid.

40 See Enrique Aguilar, Nación y Estado en el pensamiento de Ortega y Gasset, Ciudad Argentina, Buenos Aires 1998. 
The first of them, which is also the most important, is to prove that the idea of the politics of realisation is for Ortega the translation of his project of overcoming idealism into practical area. In theoretical area, this task was to be fulfilled by Ortega's ontology of life of a specific man and his metaphysics of vital reason. Their objective was to abolish the subjective content of 'idealism of idea' that was also called "the theoretical subjectivism" 41 . The last one meant for the philosopher from Madrid any metaphysical theory which originated from the acknowledgement that "the consciousness is given only its subjective conditions or «ideas»"42. It limited the reality of things to being the 'presentation' of an individual or abstract subject. Within the abolition of this standpoint, the new ontology and metaphysics based on the source fact of dynamic co-existence of an individual and their circumstances was to be constituted. Their basic category became the life interpreted as mutual 'happening' of a human being and the world represented with the metaphor of twin brothers who are born and die together.

On the other hand, the politics of realisation meant for Ortega the attempt to negate the subjective content of practical idealism which was also called "practical subjectivism"43. This standpoint embraced each concept which gave priority to ideals with belief that they were worthier than the reality (e.g. political idealism). The things were limited therein to subjective conditions and subdued to ideals interpreted as 'essence of subjectivity'. The philosopher from Madrid called this way of thinking "the magic of what it should be like" and made it the subject of his criticism. He simultaneously emphasised that its overcoming with the notion of realisation in wide-ranging social and political dimension consists in dynamic synthesis of what is ideal and real with the indication of dialectical tension occurring between what it is and what it should be like ${ }^{44}$. This synthesis is possible thanks to the abolition of abstract content of liberalism and egoistic and idolatrous interpretation of positivist progressivism, materialism and pragmatism. The result of such overcoming was Ortega's statement that ideals should be searched in the real structure of things through implementing and improving only those possibilities which were already present in them. Thus, it was about the creation of ideals on the basis of observation of the reality to escape the trap of formalism and utopianism. Pursuant to Ortega, "What should be is only what can $b e$, and what can eventually come into being is what is somehow present in what already is. It would be desirable that people have wings like birds but as they do not have them due to their natural limitations, then the statement that they should have them is false" 45 .

The thesis discussed hereinabove gives rise to further characteristics defining Ortega's idea of the politics of realisation.

First of all, the politics interpreted in such terms was in fact the pedagogy based on philosophy. Its goal was the radical reform of the Spanish mentality. It was about instilling the spirit of philosophy and science in Spanish citizens and to eliminated their "aversion to ideas

41 José Ortega y Gasset, «Kant: Reflexiones de centenario (1724-1924)», ibid., t. IV, p. 268.

42 Ibid.

43 Ibid.

44 See Domingo Hernández Sánchez, «La magia y el límite del „debe ser”. Una conexión entre "España invertebrada" y la "Ciencia de la lógica"», in Política de la vitalidad. «España invertebrada» de José Ortega y Gasset, (eds.) María Teresa López De La Vieja, Tecnos, Madrid 1996, pp. 195-204;

45 José Ortega y Gasset, «España invertebrada», ibid., t. III, p. 487. 
and theories" ${ }^{46}$. It stemmed from Ortega's belief that pedagogy - and not the traditionally interpreted politics - is the science that can change people, societies and nations (the legacy of pedagogic ideas of Francisco Giner de los Ríosa a founder of the Free Educational Institution $^{47}$, and German philosophers, including Kant and Marburg School of Neo-Kantianism. Therefore, he made pedagogy into a kind of political programme. It was based on liberalism whose meaning changed along with Ortega's philosophical development who started from reflection on the problem of Spain, on the problem of his own nation, and then proceeded with the analysis of the problem of Europe and the crisis of the entire Western culture ${ }^{48}$. In the first stage of his works, it was social liberalism emphasising the necessity of socialisation of $\operatorname{man}^{49}$. Ortega identified it with the moral idea and the 'system of revolution' focused on the goal of the entire humankind (the influence from Kant and Natorp). The education "by and for the society" and "the socialisation of the education itself" became the mission ${ }^{50}$. Such efforts were to result in the secularisation of schools and universities. Ortega searched for its basis in the philosophy interpreted as 'a theodicy, which was exemplified by the standpoints of Spinoza, Kant, Hegel, etc. In the context of this liberalism and social pedagogy, Ortega introduced the definition of democracy as the moral revival and the community work for culture. In the next stage of Ortega's thought, we deal with vital or national liberalism. It is focused on the perception of a nation as the combination of vital forces. This liberalism was manifested in Ortega's struggle with the system of Restoration, anachronisms of its structures, corruption and the fight for the Second Spanish Republic. At that time, the key task that - pursuant to Ortega - was to be fulfilled by the society was the citizenship whose absence was noticeable in almost every sphere of Spanish citizens' life. It led to the situation in which they did not want to get politically involved and they escaped responsibility which was necessary to rule the state. The Spanish politics was for him the sign of much more serious problem, that is low level of the citizens' vitality. Politics was just an "external function of living" and therefore the nation could be saved through "encouraging the Spanish people to live and only after that - to vote" 51 . During the last stage, this philosopher from Madrid significantly broadened his notion of liberalism through associating it with the growth of a mass-man and he called that phenomenon 'the revolt of the masses' ${ }^{52}$. Therefore, he reflected

46 José Ortega y Gasset, «La conservación de la cultura», ibid., t. I, p. 152

47 See J. M. Aymerich Soler, «Ortega y Giner de los Ríos: la transmisión de un legado», Revista de Estudios Orteguianos 4 (2002), pp. 155-177.

48 According to interpretation of Haro de Honrubia the evolution of liberalism in Ortega can be divided into three stages. In the first stage until 1914, liberalism and the idea of liberty are equated with the moral law. In the second, liberalism is transformed into a norm of political law, which limits the power of the state. Finally, in the third stage, liberalism becomes a vital feeling that allows to realize an individual project of life. See Alejandro Haro de Honrubia, «El pensamiento político de José Ortega y Gasset», Annales de l Seminario de Historia de Filosofía 32 (2015), p. 502.

49 About this subject wrote Ángel Peris Suay, «El socialismo en el pensamiento político de Ortega y Gasset», Contrastes. Revista Internacional de Filosofía XIX (2014), pp. 47-64.

50 See José Ortega y Gasset, «Pedagogía social como programa político», ibid., t. II, pp. 99-100.

51 José Ortega y Gasset, «Otra manera de pensar», ibid., t III, p. 38.

52 Ortega links the crisis of liberalism with the phenomenon of the rebellion of the masses, especially with the increased activity of Bolshevism and fascism, which he considers to be exemplary ideologies of the masses. These are ideologies of anti-liberal and archaic character, because they are moving Europe back to the times before the birth of liberalism. Bolshevism and fascism are an empty negation of the past. Who, however, 
not only on his own national culture but on the entire Europe and its relations with liberalism that he interpreted as $e^{2 t h o s}{ }^{53}$. At the same time, he emphasised that the European liberalism had been always the national liberalism and the idea of Europe was realised by each nation. That last idea should mean - pursuant to Ortega - the societies which implement universal Western values in a different and unique manner ${ }^{54}$.

Secondly, the politics of realisation required - pursuant to Ortega - that the state politics be transformed into the national one (it had nothing in common with generally understood nationalism because the nationalisation of politics required its Europeanisation at the same time). He clearly distinguished the competence of the state from the competence of the nation and civic society ${ }^{55}$. He vehemently criticised statism and interventionism as he considered the state as brutal and irrational force that oppressed freedom and creativity of individuals $^{56}$. In his opinion, it was the cause for increased importance of the state in the periods when masses achieved domination because the masses - similarly to the state - are anonymous. Pursuant to Ortega, the state was to be just a mechanism protecting and supporting the civic and pro-social activities. However, it cannot strive for their replacement. It is "one of the organs of the national life - but it is not the only one, not even the fundamental one" 57 . It is the state that is to be for the nation and serve it and not the opposite, and the national vitality is more important than the public order. For Ortega, the nation is the historical reality and therefore its development does not depend so much on the state as it depends on the understanding attitude of its citizens and their knowledge of their own history. Yet, it was not about the history of dates, battles, fates of prominent persons but about becoming a part of the structure of historical reality of the nation which makes it realise the limits of its possible development (Ortega's concept of historiology) ${ }^{58}$. Pursuant to this philosopher from Madrid, the history was not capable of predicting the future but it could change it into something better as it made it possible to avoid the mistakes from the past.

Thirdly, the idea of the politics of realisation assumed the organisation of the society into the ruling and the ruled ${ }^{59}$. Each healthy and efficiently functioning society is "a dyna-

denies the past, trying to erase it becomes its hostage, because the past has a returning nature. "bolchevismo y fascism - according to Ortega - son dos seudoalboradas; no traen la mañana de mañana, sino la de un arcaico día, ya usado una o muchas veces; son primitivismo. Y esto serán todos los movimientos que recaigan en la simplicidad de entablar un pugilato con tal o cual porción del pasado, en vez de proceder a su digestion". José Ortega y Gasset, «Rebelion de las masas», ibid., t. IV, p. 432. See to about this subject Jéferson Assumção, Homem-massa. A filosofia de Ortega y Gasset e sua crítica à cultura massificada, Editora Bestiário/Fundación José Ortega y Gasset-Gregorio Marañón, Porto Alegre 2012.

53 See José Luis Villacañas Berlanga, «Hacia la definición de un nuevo liberalismo. El pensamiento tardío de Ortega y Gasset», Arbor Ciencia, Pensamiento y Cultura 187 - 750 (julio-agosto 2011), p. 742.

54 About project of Europe wrote Ortega in «De Europa meditation quedam», ibid., t. X, pp. 73-137.

55 See José Maurício Carvalho, «Estado e Nação no pensamento de Ortega y Gasset», Estudios Filosóficos 6 (2011), pp. 124-142.

56 See José Ortega y Gasset, «La rebelión de las masas», ibid., t. IV, pp. 446-450.

57 José Ortega y Gasset, «Vieja y nueva política», ibid., t. I, p. 717.

58 See the project of historiology in José Ortega y Gasset, « La Filosofía de la Historia de Hegel y la historiología», ibid., t. V, pp. 229-247.

59 José Ortega y Gasset, «España invertebrada», ibid., t. III, p. 489-493. See Alejandro de Haro de Honrubia, La dialéctica masa-minoría en la filosofía de Ortega Y Gasset: Contribución al análisis de las diferentes dimensiones que los conceptos "Hombre masa" y "Hombre minoría" adoptan a lo largo de la evolución del 
mic synthesis of the mass and the elite minority" 60 . Ortega defined the mass as the average people, mediocre, who are not focused on creation of ideals and setting of goals. A concept that defines the mass is "docility". On the other hand, the elite minority is a group of outstanding and creative personalities that consciously undertake the efforts aimed at the growth of the society and culture and who define their lives by reference to higher instances and values. A concept that defines the minority is "exemplarity" 61 . The dynamic synthesis of the mass and the minority meant for Ortega their cooperation. The society - in order to be called that way - cannot be either only the elite or only the mass. The elites influence the masses through creating the ideas and setting the goals, and the mass implements and realises them. That philosopher from Madrid stated that the fundamental problem of Spain was the lack of the elite minorities and therefore it had not become the society. Therefore, the politics of realisation being a kind of unique pedagogy was aimed at the establishment of the elite minorities capable of being the leaders, which was connected with the necessity of undertaking far-reaching pedagogical reforms at all levels of education ${ }^{62}$.

Finally, the aforementioned is also the grounds for the fourth characteristics of the idea of the politics of realisation which - in the last stage of Ortega's philosophy - was to emphasise not only his national project but also the European one ${ }^{63}$. Pursuant to Ortega, the growth of the mass-man and the phenomenon of 'the revolt of the masses' was also the basic cause for the crisis in Europe which - in order to survive - has to reflect on itself, has to understand that as a society - pursuant to Ortega, there is the European society - it has to be the happening and dynamic synthesis of the mass and the minority. In his opinion, there are two forms of social existence of the Western man. The first of them is connected with their feeling of belonging to a particular nation, it is a form that is easily perceptible, with distinct contours, while the second one has the nature of broader community, the European

pensamiento orteguiano, Ediciones de la Universidad de Castilla-La Mancha, Cuenca, 2009. As the author rightly points out: the division into mass and minorities in Ortega is not primarily ethical and legal in nature, but aims to realize the real needs and potential of society: "La distinción entre minoría selecta y masa no es primariamente ética (en el sentido de la ética formalista o del deber ser kantiano) ni jurídica. Pertenece a la constitución esencial de toda sociedad. (...) Las cuestiones de ética o de derecho son secundarias. Su misión es convertirse en instrumentos al servicio de las necesidades reales". Ibid., p. 20-21.

60 José Ortega y Gasset, «España invertebrada», ibid., t. III, p. 481.

61 In this sense, the task of a minority is not to impose its vision of the world, but to educate the masses. The mass should follow the minority in a free and voluntary way. This aspect of the relationship between mass and minority is emphasized by Ignacio Sánchez Cámara in «Sobre la interpretación política de Ortega». He polemicizes with the interpretation of Elorza, who considers this relation in terms of domination. See Ignacio Sánchez Cámara, «Sobre la interpretación política de Ortega», Revista de Occidente 60 (1986), p. 142. Interpretation of Ignacio Sánchez Cámara is also confirmed by María Isabel Ferreiro Lavedán, «Minorías y masas: ni dirigentes ni dirigidos», in La actualidad de E. Kant, (eds.) Diego Medina Morales y José J. Albert Márquez, Universidad de Córdoba, Córdoba 2008, pp. 9-19.

62 José Ortega y Gasset, «Apuntes sobre una educación para el futuro», ibid., t. X, pp. 385-393. See about this subject the article of Ángel Peris Suay, «La educación de ciudadanos en Ortega y Gasset», Pensamiento 65 (2009), pp. 463-483.

63 José Ortega y Gasset, «De Europa meditatio quedam», ibid., t. X, pp. 83-84; 86-88. See Javier Zamora Bonilla «El mundo que pudo ser: el concepto "Europa” en el proyecto político orteguiano», Revista de Estudios Europeos 40 (2005), pp. 11-31. 
community and the European society ${ }^{64}$. Ortega emphasised that the basic problem of Spain and of Europe, at the same time, was a pedagogical problem consisting in the lack of the elites whose task was to direct the masses to the implementation of ideals. In his opinion, the society cannot be built without outstanding minorities. The society, in order to be healthy, has to be based on dynamic synthesis of the minority and the mass, which means the relation between those who create new ideas and set the directions for activities and those who assimilate those ideas and implement them. Therefore, the highest right that rules the social reality, the right that governs Ortega's politics of realisation is the 'biological right' of all societies consisting in the influence of the minority on the masses. As Ortega wrote: "where there is no minority that influences the mass and the mass that can accept such influence, there is no society or it is very close to the situation where would be no society"65.

The social and political reflections of Ortega, in spite of the fact that they originated in the first half of the 20th century, remain topical as they refer to two basic spheres of modern Western man's life: the national sphere and the European sphere, and to their mutual relations. For some time, both of them have been seen as problematic (the current crisis of European unity and solidarity, the revival of nationalisms, unclear relation between the national and European politics, etc.), and therefore they need to be explained and defined. Ortega's social and political philosophy turned into the formula of the politics of realisation is one of the attempts to solve this problem and explain such notions as 'nation', 'Europe', 'society', 'state', 'unity', 'diversity', etc. and the relations existing between them.

\section{Bibliography}

ACCIAIOLI, E. (2013): «Ortega y Hegel: un diálogo fructífero», Revista de Estudios Orteguianos 27, 247-249.

AGUILAR, E. (1998): Nación y Estado en el pensamiento de Ortega y Gasset, Ciudad Argentina, Buenos Aires.

ASSUMÇÃO, J. (2012): Homem-massa. A filosofia de Ortega y Gasset e sua crítica à cultura massificada, Editora Bestiário/Fundación José Ortega y Gasset-Gregorio Marañón, Porto Alegre.

AUBERT, P. (2000): «Los intelectuales y la II República», Ayer 40, 105-135

AYMERICH SOLER, J. M. (2002): «Ortega y Giner de los Ríos: la transmisión de un legado», Revista de Estudios Orteguianos 4, 155-177.

BAGUR TALTAVULL, J. (2014): «José Ortega y Gasset en el movimiento reformista: la Liga de Educación Política Española como proyección del "patriotismo fenomenológico" (1913-1916)», Ab Initio 10, 153-188.

CACHO VIU, V (2000): Los intelectuales y la política. Perfil público de Ortega y Gasset, Biblioteca Nueva, Madrid.

64 See Jesus J. Sebastian Llorente, «La idea de Europa en el pensamiento político de Ortega y Gasset», Revista de Estudios Políticos (Nueca Epoca) 83 (1994), pp. 221-245.

65 José Ortega y Gasset, «España invertebrada», ibid., t. III, pp. 480-481. 
CANTILLO, C. (2016): «La dinámica histórica entre energía mediterránea y pensamiento del norte: la confrontación de Ortega con Hegel», in (ed.) P. Badillo O'Farrell y J. M. Sevilla Fernández, La brujula hacia el sur, Biblioteca Nueva, Madrid, 87-100.

CEREZO GALÁN, P. (2011): José ortega y Gasset y la razón práctica, Biblioteca Nueva, Madrid.

CEREZO GALÁN, P. (1984): La voluntad de aventura. Aproximamiento critico al pensamiento de Ortega y Gasset, Ariel, Barcelona.

CHAMIZO DOMÍNGUEZ, P. J. (1985): Ortega y la cultura española, Cincel, Madrid.

CRAMER, K. (1989): «Ortega y Gasset y la filosofia alemana», in M. Cruz (ed.), Historia, lenguaje, sociedad, Crítica, Barcelona, 186-204;

FERREIRO LAVEDÁN, M. I. (2008): «Minorías y masas: ni dirigentes ni dirigidos», in(eds.) D. Medina Morales y J. Albert Márquez, La actualidad de E. Kant, Universidad de Córdoba, Córdoba, 9-19.

GARRIGUES, E. (1983): «Ortega en su circunstancia alemana», Humboldt 79, 53-63.

HARO HONRUBIA, A. de (2008): «El advenimiento de la Segunda República española desde la óptica de José Ortega y Gasset: la importancia de la Agrupación al Servicio de la República (ASR)», in La escarapela tricolor. El republicanismo en la España contemporánea, (ed.) C. Cabrero Blanco, KRK/Universidad de Oviedo, Oviedo, 409-423.

HARO HONRUBIA, A. de (2015): «El pensamiento político de José Ortega y Gasset», Annales de 1 Seminario de Historia de Filosofía 32, 477-515.

HARO DE HONRUBIA, A. de (2009): La dialéctica masa-minoría en la filosofía de Ortega Y Gasset: Contribución al análisis de las diferentes dimensiones que los conceptos "Hombre masa" y "Hombre minoría" adoptan a lo largo de la evolución del pensamiento orteguiano, Ediciones de la Universidad de Castilla-La Mancha, Cuenca.

HARO HONRUBIA, A. de (2003): «La idea de progreso en la era del nihilismo: Ortega y su crítica al progresismo», Revista de la Escuela Universitaria de Magisterio de Albacete 18, 133-154.

HEGEL, G. W. F. (1971-1978): Werke in 20 Bänden, (hrsg.) E. Moldenhauer, K. M. Michel, Suhrkamp, Frankfurt/M.

HERNÁNDEZ SÁNCHEZ, D. (2000): Estética de la limitación. La recepción de Hegel por Ortega y Gasset, Ediciones Universidad de Salamanca, Salamanca.

HERNÁNDEZ SÁNCHEZ, D. (1996): «La magia y el límite del „debe ser”. Una conexión entre "España invertebrada" y la "Ciencia de la lógica"», in (ed.) María Teresa López De La Vieja, Política de la vitalidad. «España invertebrada» de José Ortega y Gasset, , Tecnos, Madrid, 195-204;

LESZCZYNA, D. (2017): Hegel w Hiszpanii. Od szkoły sewilskiej do szkoły madryckiej, Wydawnictwo Marek Derewiecki, Kęty.

MAURÍCIO CARVALHO, J. (2011): «Estado e Nação no pensamento de Ortega y Gasset», Estudios Filosóficos 6, 124-142.

MENÉNDEZ ALZAMORA, M. (2015): La generación del 14. Intelectuales y acción política, Catarata, Madrid.

MORÓN ARROYO, C. (1968): El sistema de Ortega y Gasset, Alcalá, Madrid.

ORRINGER, N. R. (1979): Ortega y sus fuentes germánicas, Gredos, Madrid. 
ORTEGA Y GASSET, J. (2007): Hegel. Notas de trabajo, (ed.) Domingo Hernández Sánchez, Fundación Ortega y Gasset / Abada editores, Madrid.

ORTEGA Y GASSET, J. (2004-2010): Obras completas, 10 voll., Fundación José Ortega y Gasset-Taurus, Madrid.

PERIS SUAY, Á. (2014): «El socialismo en el pensamiento político de Ortega y Gasset», Contrastes. Revista Internacional de Filosofía XIX, 47-64.

PERIS SUAY, Á (2009): «La educación de ciudadanos en Ortega y Gasset», Pensamiento 65, 463-483.

QUEIPO DE LLANO, G., TUSELL, J. de (1990): Los intelectuales y la República, Narea, Madrid.

SAN MARTÍN, J. (2012): La fenomenología de Ortega y Gasset, Biblioteca Nueva, Madrid.

SAN MARTÍN, J. (2005): «Ortega en Alemania», in (ed.) J. Lasaga Medina, El Madrid de José Ortega y Gasset, Publicaciones de la Residencia de Estudiantes / Sociedad Estatal de Conmemoraciones Culturales, Madrid, 331-348.

SÁNCHEZ CÁMARA, I. (1986): «Sobre la interpretación política de Ortega», Revista de Occidente 60, 142-152.

SEBASTIAN LLORENTE, J. J. (1994): «La idea de Europa en el pensamiento político de Ortega y Gasset», Revista de Estudios Políticos (Nueca Epoca) 83, 221-245.

VILLACAÑAS BERLANGA, J. L. (2011): «Hacia la definición de un nuevo liberalismo. El pensamiento tardío de Ortega y Gasset», Arbor Ciencia, Pensamiento y Cultura 187 $-750,741-754$.

ZAMORA BONILLA, J. (2005): «El mundo que pudo ser: el concepto "Europa" en el proyecto político orteguiano», Revista de Estudios Europeos 40,11-31.

ZAMORA BONILLA, J. (2002): Ortega y Gasset, Plaza y Janés, Barcelona. 
